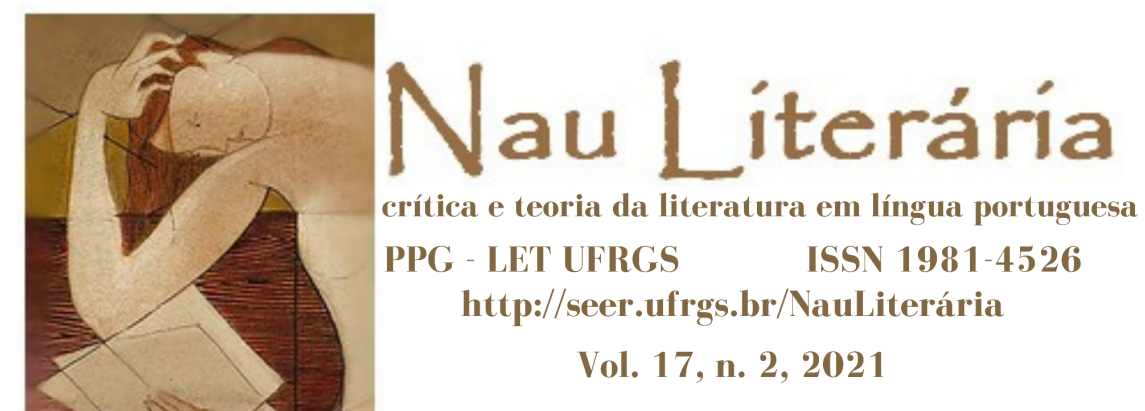

\title{
Márcio Souza e o judaísmo: a questão das nomenclaturas étnicas na literatura brasileira
}

\section{Márcio Souza and judaism: a question of ethnical terminology in brazilian literature}

João Carlos de Carvalho ${ }^{1}$

\begin{abstract}
RESUMO: A proposta de discussão teórica implica um enfrentamento a partir do conceito de retalhos de memória. A ideia de releituras palimpsésticas produz ao ensaísta o desafio de remexer as pistas invisíveis de sua origem judaica. Nesse caso, ao partir em busca das relíquias do passado, a escrita se lança ao abismo, submetendo-se ao risco de produzir sensações e imagens capazes de conciliar o presente e o passado. O artigo retoma um ensaio de Márcio Souza, "A verdadeira nação de Rafael Bentes", conhecido autor amazonense, onde ele, sob o foco de (re)encontrar-se com sua judeidade sefaradita, procura evocar as condições de um trajeto, não para descrever o percurso propriamente, mas para possibilitar o testemunho de reconstrução, sob a égide benjaminiana, relido à luz da dinâmica de produção do sensível ao próprio discurso histórico e memorial.
\end{abstract}

PALAVRAS-CHAVES: Expressão amazônica; Ensaio; Judiedade; Márcio Souza

ABSTRACT: The proposal of theoretical debate implies a confrontation through the concept of memorial patchwork. The idea of palimpsest re-readings establishes an essayistic challenge to rummage the invisible footprints of its Judaic origin. In this case, at the beginning of the quest for the relics of the past, writing launches into the abyss, submitting to the risk of creating sensations and images able to merge present and past. The article retakes a Márcio Souza's essay, "A verdadeira nação de Rafael Bentes", known as an Amazonian author, where under the focus of his rendezvous in the Sephardic Judaism, attempts to evoke conditions for a pathway, not only to describe it properly, but to provide a testimony of reestablishment under the benjaminian orientation, that shed light to the dynamics of creation from sensible to its historical and memorial discourse.

KEYWORDS: Amazonian expression; Essay; Judaism; Márcio Souza

\footnotetext{
${ }^{1}$ Professor da área de Teoria da Literatura da Universidade Federal do Acre, Campus Floresta. Mestrado na UFRJ. Doutorado na Unesp de SJRP
} 


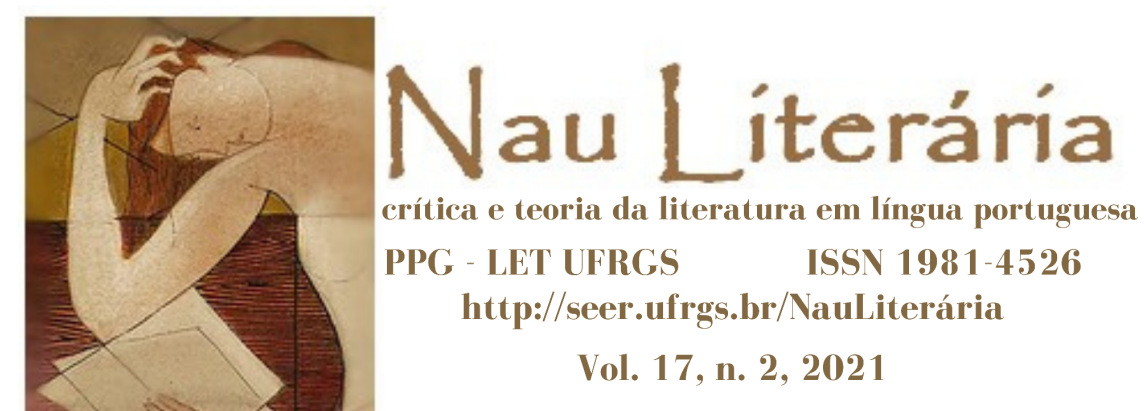

Depois de passar quatro anos estudando a obra do escritor amazonense Márcio Souza e relacionando-a à tradição literária regional brasileira, em particular a de expressão amazônica, acabei por me debruçar sobre um ensaio, publicado em 2000, em que o autor de Galvez, imperador do Acre reconhece a sua ascendência judaica. O livro passou um pouco despercebido à época, em relação ao sucesso de seus romances publicados entre as décadas de 1970, 1980 e início dos anos 1990, mas, para qualquer pesquisador das letras locais, e em particular de um escritor tão profícuo como Márcio Souza, não se pode deixar de perceber a importância desse autorreconhecimento para compreendermos a gênese da sua obra como um todo, em uma certa altura. O livro foi escrito em parceria com Moacir Scliar, escritor gaúcho, que nunca escondeu a sua problemática de ser em relação à sua origem hebraica, já que ele, filho de judeus russos, viu-se desde cedo, mesmo nascendo no Brasil, obrigado a enfrentar as marcas que trazia em sua genealogia emigrante. Sem dúvida, quem leu uma relativa parte da obra do autor de $O$ exército de um homem só não pode deixar de perceber as formas de temática obsessiva em torno das crenças e descrenças herdadas em seu meio étnico porto-alegrense.

Com a publicação de Entre Moisés e Macunaíma: os judeus que descobriram o Brasil, entramos em contato com maneiras distintas de dois importantes escritores brasileiros ao encarar sua ascendência hebraica, cada um oriundo de um extremo do país. No caso, Moacir Scliar fala do sentimento de ser judeu no Brasil, retomando o sentido de errância pelo mundo desse grupo e a luta por um espaço de liberdade e sobrevivência (SCLIAR, 2000, p. 9). Márcio Souza dá seu testemunho de ter sabido já adulto que os sobrenomes Bentes e Sevalho, de seus pais, descendiam dos sefaraditas marroquinos $^{2}$, emigrados em peso para a Amazônia desde 1810, por diversas razões. De uma maneira geral, seu ensaio versa sobre a assimilação dessa gente em nosso país e a

\footnotetext{
${ }^{2}$ Sefaradita, ou sefardita, pode ser traduzido como judeu espanhol ou da Península Ibérica, ou mesmo do Sul da França e/ou parte da Itália.
} 


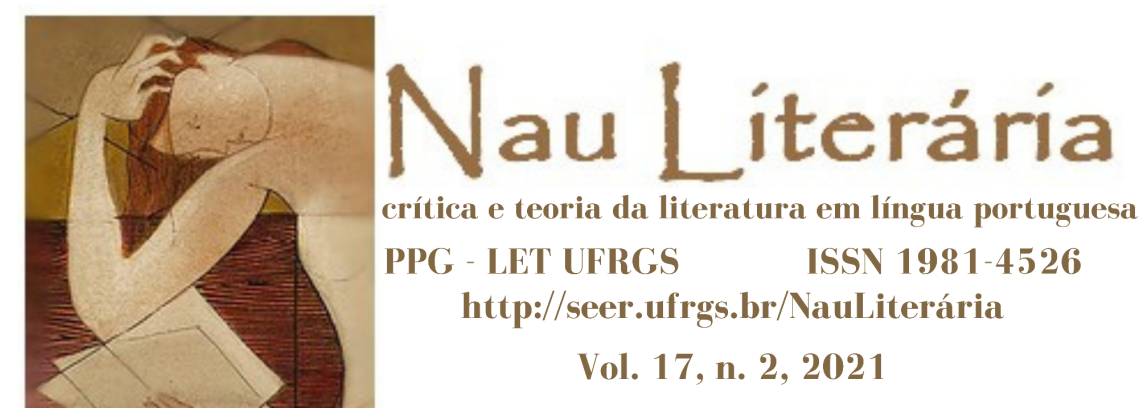

maneira como ele se identificou com o sentido de ser judeu muito além do religioso (SOUZA, 2000, p.118). Em 2010, Márcio Souza, depois de oito anos da publicação desse livro, adaptou a obra Eretz Amazônia: os judeus na Amazônia ${ }^{3}$, de Samuel Benchimol, a uma peça em sete atos, contando a saga dos judeus marroquinos ao chegar ao Pará e transitar pelo interior da região até chegar em Manaus e, dali, continuar se espalhando.

A problemática judaica, há centenas de anos, sempre foi a de adaptação aos lugares em que seus membros se viram obrigados a emigrar pelo mundo, quase sempre por razões persecutórias. Essa questão da errância, portanto, é muito forte para todos os judeus, assimilados ou não, religiosos ou seculares, e é visível nas obras de tantos escritores, pintores, músicos, cientistas, pensadores etc., pelo mundo. Trata-se do único povo da antiguidade que manteve as suas tradições através dos séculos até hoje ${ }^{4}$. Sendo assim, mesmo que um judeu assimilado se torne um crítico acerbo da sua religião e seus costumes e atavismos, ele jamais poderá apagar de sua memória as questões fulcrais deixadas por rastros infinitos de seus antepassados entre as marcas da perseguição sofrida, mesmo em seu inconsciente.

Por ser uma religião bastante rígida nos seus modos e costumes, por temer qualquer forma de contaminação a sua doutrina original, o judaísmo se projetou e se projeta no mundo como uma expressão capaz de manter um elo fortíssimo mesmo entre “as ovelhas desgarradas". É praticamente impossível para o sujeito, filho de pais judeus, ou ciente de seus antepassados, não ser atravessado, durante a vida, pelo destino do ser judaico.

Ao sair da Europa, ainda nos primeiros séculos da colonização, os judeus que chegavam ao Brasil, na sua esmagadora maioria, começaram um processo de

\footnotetext{
${ }^{3}$ Eretz, em hebraico, quer dizer terra.

${ }^{4}$ Sumérios, acádios, hititas, assírios, babilônios, fenícios, todos desapareceram, enquanto os judeus "há quatro mil anos dão provas de uma coesão que os une entre si e que lhes permitiu conservar sua identidade através dos séculos." (SHAPIRO, 1970, p. 111-2)
} 


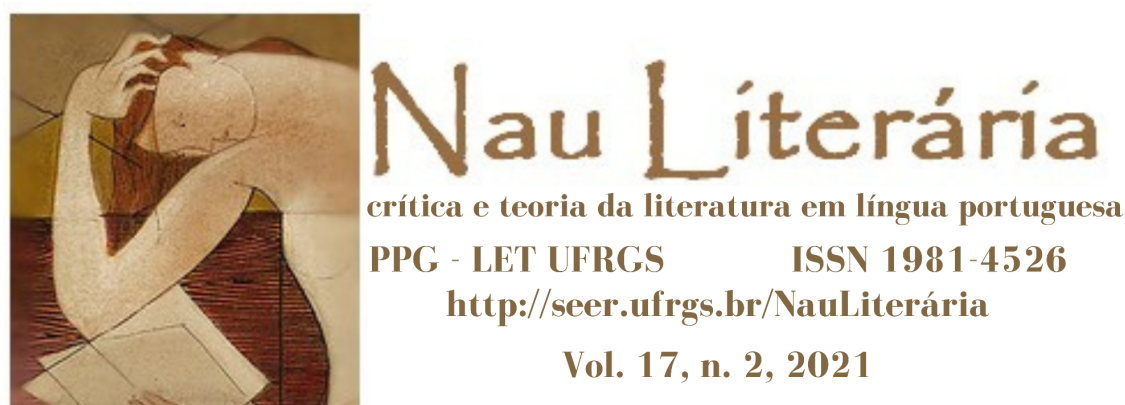

assimilação ou de conversão para outras crenças, inevitável ${ }^{5}$. Na Europa, na Idade Média e na Idade Moderna, viviam em pequenas comunidades, muitas vezes à margem. Conseguiram se firmar, quase sempre, como negociantes ou em profissões liberais, e se comunicavam internamente em iídiche ou haquitia - línguas próprias de resistência ao meio sempre hostil em que habitavam, pois sujeitos ao antissemitismo, mesmo ocupando posições de destaque nas artes ou nas ciências ${ }^{6}$. Nos Estados Unidos, que se apresentava como terra da liberdade, apesar de nunca sofrerem perseguições sistemáticas como na Europa, os judeus, até mesmo os secularizados, sentiram na própria pele também alguma forma de antissemitismo ou discriminação mais sistemáticas, o que fez com que eles se abrigassem em guetos étnicos nos grandes centros urbanos daquele país. Isso tornou a assimilação menos intensa do que no Brasil. $\mathrm{Na}$ Europa, com a Inquisição recrudescida no início da Era Moderna ${ }^{7}$, os pogroms ${ }^{8}$, e depois o holocausto (ou Shoah) nazista ${ }^{9}$, ao longo dos séculos, despertaram cicatrizes

\footnotetext{
${ }^{5}$ A conversão era inevitável, pois foi forçada. Daí a denominação de "Ben Anussim", termo hebraico transliterado que se traduz como "filho dos forçados", onde se entende que TODO descendente de cristãos novos - que tem a sua matrilinearidade intacta. Muitos vieram para o Brasil convertidos e já pertenciam a 2a ou 3a geração dos judeus expulsos de Espanha e Portugal. Daí esses sobrenomes portugueses patronímicos, toponímicos, etc. Ninguém teve escolha, na verdade. Existe uma outra categoria: os "cripto-judeus", que são os judeus que não se converteram, mas vivem secretamente o seu judaísmo sob a aparência cristã. (Agradeço esta nota a Wânia de Castro Baena, minha amiga. Grande estudiosa do judaísmo).

${ }^{6}$ lídiche era a língua dos judeus askenazitas e haquitia dos judeus sefaraditas.

${ }^{7}$ Sujeitos a todo tipo de regulamentação nesse período, os judeus se viram muitas vezes obrigados à conversão, e mesmo assim sofriam perseguições sistemáticas como cristãos novos. Para conservar sua fé, emigraram da Espanha e de Portugal para Holanda ou para o norte da África, como nos explica Samuel Benchimol. (2008, p. 31-40)

${ }^{8}$ Os pogroms consistiam, na Rússia czarista, em pilhagens, perseguições e assassinatos, sob a autorização oficial do Estado.

${ }^{9}$ Atualmente, os estudiosos preferem o termo Shoah (catástrofe, em hebraico), ao invés de holocausto. O primeiro se adequaria melhor ao destino judaico, diante do extremo antissemitismo europeu à época, em países germânicos ou eslavos. O segundo termo, que quer dizer sacrifício, não mais iria ao encontro das condições cruéis em que milhões de seres humanos foram despoticamente tratados por um regime assassino. Essas milhões de pessoas não se sacrificaram por livre e espontânea vontade. Foram pegas de surpresa por uma doutrina que visava a sua destruição enquanto povo, baseada em teorias pseudocientíficas e na loucura de líderes que imaginavam estar criando uma nova ordem de superexclusão em nome da pureza racial e ideológica. No fundo, o nazismo não passava de uma doutrina do mal profundo, de retomada de resquícios tribais mais detestáveis, onde todo tipo de gente da pior
} 


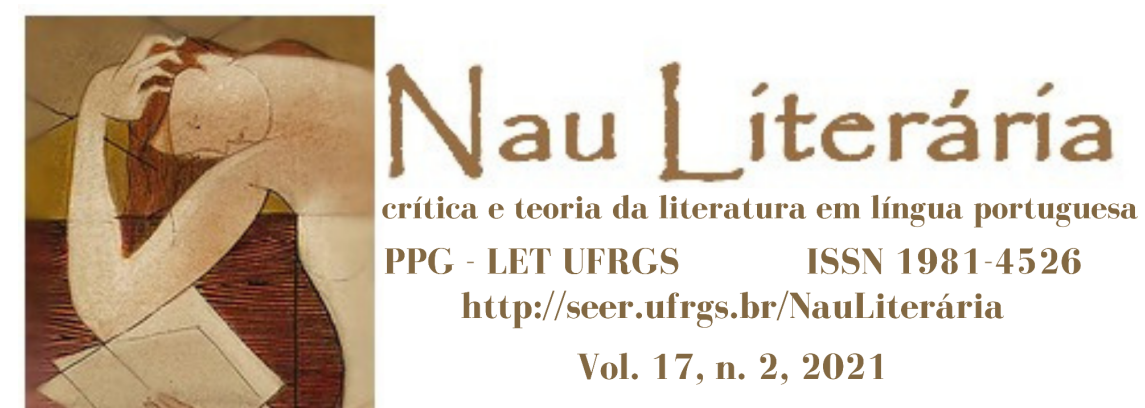

imponderáveis que marcaram o judaísmo como um destino inexorável até hoje, ainda na era contemporânea, obrigando a muitos judeus a se deslocarem pelo mundo mesmo no século XX, e finalmente criar um Estado próprio no Oriente Médio sob o beneplácito das Nações Unidas em 1947.

No Brasil, os judeus, que emigraram entre o século XIX e o século $\mathrm{XX}$, já encontraram um povo, de uma maneira geral, indiferente, na maioria das vezes, a sua ascendência. Os que foram chegando, iam naturalmente assimilando as marcas da cultura local. Aqueles que praticavam livremente sua fé não eram importunados pelo Estado ou por qualquer ação discriminatória importada ou direta, isso já com D. João VI, ou principalmente depois da Proclamação da República que tornou o estado laico. Talvez por isso mesmo, acabaram tendo dificuldades para manterem a tradição através dos seus descendentes. Se, em relação aos descendentes de escravos africanos, pesou, ou ainda pesa, alguma forma de racismo entre nós, com os judeus, se houve qualquer preconceito $^{10}$, não seria muito diferente da discriminação a outros grupos estrangeiros, ao longo do século XX. Portanto, para os estudiosos da literatura brasileira, seria uma tarefa muito difícil, mas não impossível, detectar marcas do povo errante em nossas letras e encontrarmos uma literatura judaica entre nós se tomarmos simplesmente o sentido de deslocamento desse povo para cá, principalmente entre os assimilados. Por outro lado, pergunto, poderíamos usar o termo escritor judeu-brasileiro para um grupo de produtores das letras que se destacou, ou se destaca, entre nós? Assim, como existe o escritor judeu-americano ou afro-americano nos EUA?

Desde os anos 1990, o termo literatura afro-brasileira tem sido insistentemente usado em muitos estudos multiculturais. Mas seria, por exemplo Machado de Assis, um escritor afro, por ser de maneira indubitável um mestiço? Ele, tão bem assimilado às

espécie, fosse vinda dos estratos mais baixos ou mais altos das sociedades germânicas, teve a oportunidade de colocar em prática toda forma de perversidade.

${ }^{10}$ Com exceção do breve período getulista que procurou limitar a vinda de judeus para o país, durante a Segunda Grande Guerra. 


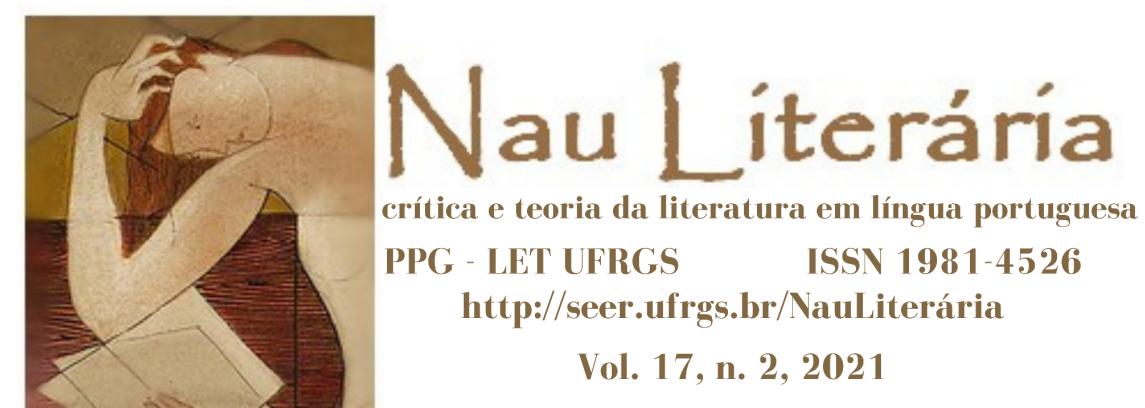

condições da vida em sociedade do Brasil Império e do Brasil da Primeira República, muito longe de sofrer as agruras que os escravos, ou seus filhos e netos, vivenciaram por meio do preconceito à cor da pele ou pela posição social desprestigiada? No meu modo de ver sim, mas não pelas razões habituais, porém, principalmente, como observador arguto que o escritor se tornou. Da mesma maneira, como um Lima Barreto ou uma Carolina de Jesus, vivendo em um período pós-escravocrata, mas sentindo o estigma e o destino do povo de ascendência africana de uma maneira ou de outra. $\mathrm{O}$ primeiro como um intelectual deslocado social e academicamente na Primeira República, e a segunda fazendo da fome uma grande personagem de seus diários, mostrando uma condição muito particular de captar a vida em uma favela de grande cidade brasileira em meados do século XX. Esses dois e outros tantos e tantos afrodescendentes, que detectaram as formas de afirmação do negro ou do mestiço em nosso país pós-escravidão, poderiam se enquadrar dentro de uma determinada perspectiva conceitual, o que não deixa nunca de ser problemática até hoje o de usar este ou aquele enquadramento para tratarmos de um fenômeno literário. Nesse caso, acredito que o importante seria não nos limitarmos a nenhum conceito prévio, alargando-o sempre que necessário.

Quando tentamos inventariar alguns dos escritores de ascendência judaica em nosso país, pelo menos aqueles que mais se destacaram contemporaneamente, podemos perceber que a questão não é assim tão clara, mas que nos convida a algumas reflexões importantes, principalmente em relação à maneira de registro da sua condição itinerante, herdada de seus antepassados, recentes ou não. Ao trabalhar com o ensaio de Márcio Souza, "A verdadeira nação de Rafael Bentes"11, procurarei investigar como as marcas de uma ascendência tão forte podem se manifestar na escrita literária do presente e do futuro, em um escritor que até numa determinada altura desconhecia a origem de seus

\footnotetext{
${ }^{11}$ O título do ensaio de Márcio Souza faz referência ao romance de Moacir Scliar "A estranha nação de Rafael Mendes". Neste livro, Scliar tenta mostrar como o Brasil, de certa maneira, teve entre seus construtores, a participação decisiva dos cristãos novos, ou judeus assimilados ou os convertidos à força.
} 


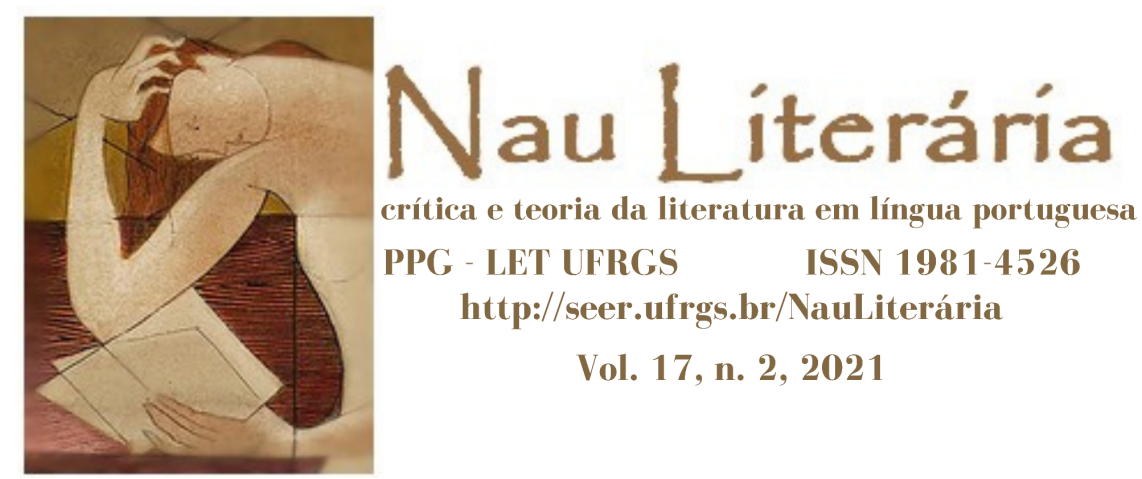

antepassados mais remotos, quando se deparou com o livro de Samuel Benchimol. ${ }^{12}$ A pesquisadora Regina Igel nos lembra que o registro dos escritores judeus, desde a era colonial portuguesa, sempre foi diminuta e imperceptível, por questões mesmo de sobrevivência diante da sanha inquisitorial. (2000, p. 326) E mais adiante tenta mostrar que houve, principalmente, no século XX, uma "literatura tipificante" em torno da temática judaica no Brasil, principalmente no Rio Grande do Sul, porém, quase sempre transitando entre o documental e o literário. O destaque vai, sem dúvida, para Moacir Scliar. (IGEL, 2000, p. 326-27)

Antes de avançarmos para o ensaio de Márcio Souza, algumas reflexões se fazem necessárias. É possível, sem dúvida, rastrearmos uma literatura de caráter judaico de alta qualidade entre nós, inconsciente ou não. Moacir Scliar esmerou-se em desdobrar esse tema em sua literatura ficcional, como já foi percebido pela crítica e pelos seus leitores. São inúmeros os seus romances que versam de diferentes maneiras sobre o ser judaico nacional. No entanto, entre outros escritores, essa questão não aparece tão claramente. Se retomarmos Clarice Lispector, onde a questão da estrangeiridade a incomodava deveras, por outro lado, não é difícil percebermos em seus livros uma inquietude que vai além do ser feminino, ou meramente existencial, pois suas personagens irradiam uma itinerância extraordinária, ou uma divagação clássica judaica que as fazem dar voltas sobre o mesmo ponto e cada vez mais aprofundar a relação entre a essência e a dispersão. Suas personagens podem ser vistas como seres em busca de uma identidade muito mais inconsciente do que aquela perceptível à primeira vista. Elas jogam com o desafio de aceitar o tropeço ou as muletas como os artifícios de redescoberta de adaptabilidade. Samuel Rawet, que numa certa altura de sua vida literária luta contra o ser judeu que trazia em si, não deixou de

\footnotetext{
${ }^{12}$ Alguns escritores de ascendência judaica de destaque na literatura brasileira contemporânea: Clarice Lispector, Samuel Rawet, Moacir Scliar, Márcio Souza, José Santiago Naud, Michel Laub e Arnaldo Bloch. Esses se fizeram conhecer não apenas pela ascendência hebraica, mas por uma qualidade artística elevada de seus textos
} 


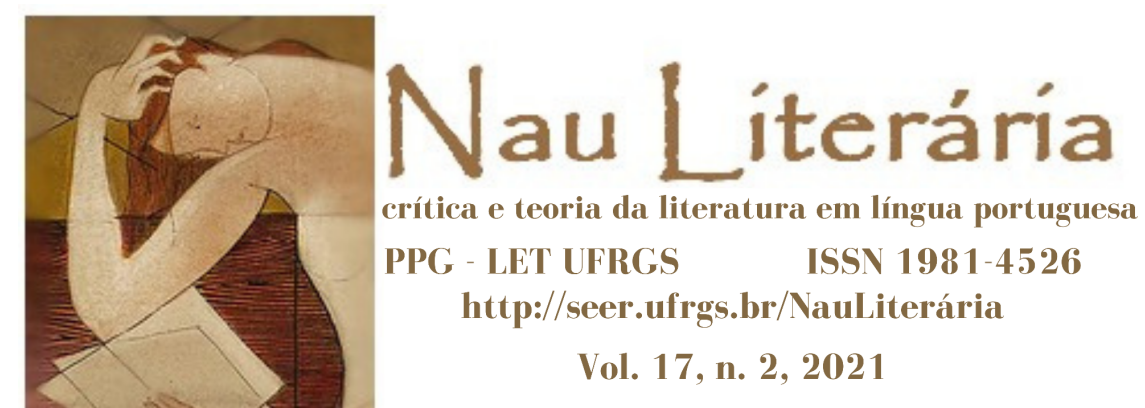

fazer de sua obra - hoje, um tanto esquecida - um depoimento do sujeito deslocado por excelência. $\mathrm{O}$ estrangeiro em si toma conta da sua condição itinerante e redescobre os passos não dados como o mais importante. Michel Laub, mais recentemente, em um único romance até agora, $O$ diário da queda, tenta retomar a questão da problemática judaica em nosso país como uma disputa eterna que cada ser judeu traz dentro de si e que, de qualquer maneira, terá de resolver no seu próprio íntimo.

Quando um autor tão complexo como Philip Roth é chamado de escritor judeu-americano, já sabemos que, pela própria história estadunidense, isso tem muito mais a ver com as condições de guetificação a que os grupos étnicos ficaram submetidos na construção daquele país. Woody Allen, famoso cineasta e escritor, é visto como portador de um humor judaico. Por outro lado, afro-americanos são vistos como minoria naquele país, e os judeus não. ${ }^{13}$ No Brasil, a questão das minorias, influenciada pelos estudos multiculturalistas norte-americanos, tenta incluir negros, mulheres, membros da comunidade LGBTQI+, comumente, como membros de minorias. Porém, tal como nos Estados Unidos, os judeus ou seus descendentes não são vistos como uma etnia capaz de suscitar estudos nessa direção. Talvez por serem brancos, ou por Israel ter ocupado os territórios palestinos para garantir sua segurança nacional, com assentamentos, o judeu não é interpretado, no âmbito acadêmico universitário atual, entre nós, como um ser oprimido, como o foi até um passado recente. As perseguições sofridas na inquisição ibérica, ou as conversões forçadas ao longo dos séculos, ou a catástrofe (holocausto) nazista, tudo isso, e muito mais, não pesa para que a expressão literária judaica entre nós seja examinada com mais acuidade pelos estudiosos multiculturalistas e, no caso, inserida dentro de uma problemática importante da

\footnotetext{
${ }^{13}$ Sociologicamente, minoria é um conceito, comumente, onde um grupo é controlado por outro. Acredito que, no entanto, o conceito pode ser mais alargado. Qualquer grupo étnico, que não se enquadre dentro de determinados padrões determinantes, pode ser considerado uma minoria. Como pensamos o conceito a partir de um "desprivilégio", os judeus nos EUA e no mundo conseguiram reverter essa condição em seu benefício e se afirmaram como uma espécie de unidade que ainda luta pelo seu espaço de reconhecimento ainda, até hoje.
} 


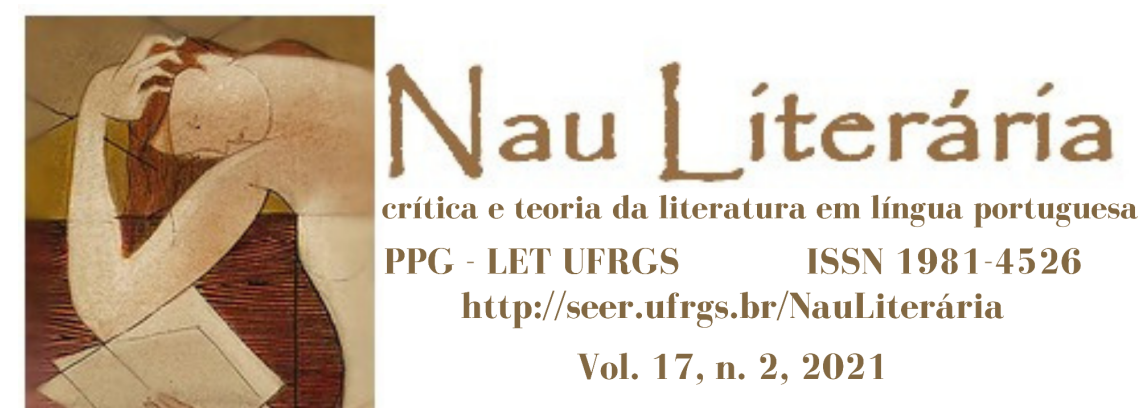

evolução de nossas letras, sob um ângulo muito mais amplo da relação "opressor versus oprimido". ${ }^{14}$

A proposta de trabalho que trago aqui tem a ver com a reconstrução dos retalhos de memória. Retomando o conceito de história de Walter Benjamin, Seligman-Silva o torna uma ideia de recuperação mnemônica. A literatura nesse sentido seria um testemunho da reconstrução antes de tudo em nosso tempo, onde a lembrança e o esquecimento quase não se opõem. (2003, p. 388) Mais adiante ele nos diz que, ao explorarmos esse aspecto na história e na literatura, deparamo-nos com "um palimpsesto aberto a infinitas re-leituras e re-escritas". (SILVA, 2003, P. 389) Acho que é exatamente por aí que devemos enfrentar o tão instigante ensaio de Márcio Souza onde ele revolve as suas raízes judaicas. Por ter descoberto já adulto que os sobrenomes de seus pais remetiam à origem sefaradita-marroquina, o escritor se viu desafiado a enfrentar uma memória inconsciente. Essa memória, na verdade, será reinventada pela magia literária ou poética. Seligman-Silva, ainda baseado em Walter Benjamin, fala-nos da captação da memória involuntária como imagem, nunca como uma maneira de descrever tão somente um trajeto. "Ler o que nunca foi escrito", na verdade, expressão profética do destino do ser judeu nas eras moderna e contemporânea, do poeta Hofmannsthal, (SILVA, 2003, p. 399) torna-se a base para muitos historiadores, ensaístas, literatos, de uma maneira geral, para procurar as marcas de um rastro inconsciente. O destino de Márcio Souza, como escritor brasileiro e amazônida, de repente será atravessado por uma questão oblíqua mesmo em confronto aos pontos consagrados mais prementes da sua produção ficcional ou dramatúrgica, por exemplo. O ser judeu é remexido e reencontrado de maneiras desconcertantes pela sua pena ensaística. O cristão novo, ou o judeu assimilado ao grande vale verde amazônico, é despertado e o encontro com suas raízes, até então desconhecidas, ganha uma urgência

\footnotetext{
${ }^{14}$ Evidentemente, o conceito de evolução aqui se insere dentro de um complexo, e não no sentido progressista que muitas vezes dão ao termo.
} 


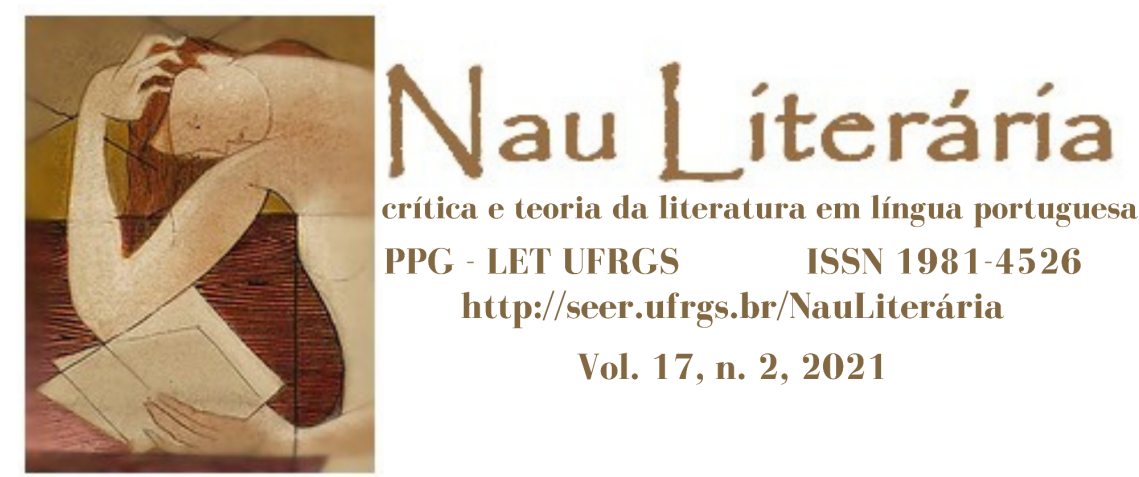

imagística, muitas e decisivas vezes. Revolver o passado será sempre o de se deparar com algum intermédio de "mutilação". (SILVA, 2003, p. 404) Interpretar o passado é aceitar as condições de uso dessa "memória involuntária", desse bric-à-brac de esparsos desvãos que a ausência sempre seduz para um preenchimento do esparso, reencontrado em tantos outros escritos, perfis, espelhos, cemitérios, artesanatos, enfim, relíquias de uma urgência de reconhecimento que, no fundo, não passam de rastros a serem sempre perquiridos por mentes inquietas. A escrita tenta dar o tom, ou buscar a forma que a lança ao abismo e ao mesmo tempo segura o escritor até o último momento, para que o caos possa apenas ser vislumbrado e sirva então como mote de uma nova redescoberta. O judeu assimilado ou secularizado sente dentro de si essa necessidade do registro de uma saga que continua a ser contada, entre contradições sempre ferozes de um risco que se aprimora na própria atividade da escrita.

Em seu livro, Raizes judaicas no Brasil, Flávio Mendes Carvalho, depois de ampla pesquisa, faz um extraordinário inventário das perseguições sofridas pelos cristãos novos em nosso país, ao longo dos anos de sanha inquisitorial. O Santo Ofício só seria abolido entre nós com a vinda da família Real Portuguesa, por Dom João VI, na segunda década do século XIX. É impressionante o número de pessoas condenadas à fogueira, ou ao hábito perpétuo, ou ao cárcere, ou mesmo ao degredo - todos por práticas judaizantes, geralmente dissimuladas, e com sobrenomes tão comuns entre nós brasileiros, até hoje, descendentes de ibéricos. ${ }^{15}$

\footnotetext{
${ }^{15}$ A lista é imensa, mas vale a pena, ao menos, reproduzir os sobrenomes mais utilizados por cristãos novos no Brasil para esconder a sua ascendência judaica, entre os séculos XVII e XVIII. Todos os portadores desses sobrenomes que aparecem na lista foram condenados pelo Santo Ofício: Abreu, Afonso, Aguiar, Aires, Albuquerque, Almeida, Alonso, Alvarenga, Álvares, Alves, Amado, Amaral, Andrade, Antunes, Araújo, Assunção, Ataíde, Ávila, Azevedo, Bacelar, Balboa, Batista, Barbosa, Barreira, Barreto, Barros, Barroso, Bastos, Beirão, Belmonte, Bentes, Bernardes, Bezerra, Bicudo, Bispo, Bivar, Bonsucesso, Borges, Borralho, Botelho, Bragança, Brandão, Bravo, Brito, Bueno, Bulhão, Cabral, Cabreira, Cáceres, Caetano, Caldas, Caldeira, Caldeirão, Camacho, Câmara, Caminha, Campos, Candeias, Capote, Cárceres, Cardoso, Carneiro, Carreira, Carrilho, Carvalho, Casado, Casqueiro, Castanheda, Castanho, Castelo, Castelhano, Castilho, Castro, Chaves, Cid, Coelho, Colaço, Contreiras, Cordeiro, Coronel, Correia, Cortês, Costa, Coutinho, Couto, Covilhã, Crasto, Cruz, Cunha, Delgado, Diamante, Dias, Diniz, Dionísio, Dória, Dourado, Duarte, Escobar, Espadilha, Espinoza, Esteves, Évora, Faísca, Falcão, Faria, Farinha, Faro,
} 


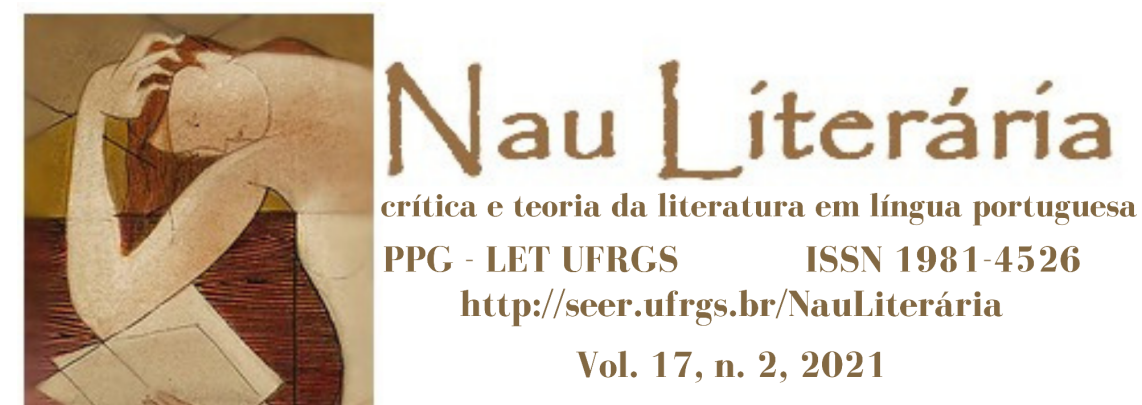

A atuação inquisitorial entre nós, por praticamente dois séculos (XVIII e XVIII), de maneira intensa, tentou obscurecer, antes de tudo, a memória do ser errante. Procurou de todas as formas abafar os resquícios de um trajeto que fez milhares de pessoas buscar refúgio e conforto por aqui e muitas vezes se viram ferozmente perseguidas, porque nem sempre o sobrenome escondia os maneirismos judaicos herdados, sobretudo o que fosse capaz de despertar um reino de suspeita e terror nos primeiros séculos da nossa colonização. Principalmente, porque a ascendência invisível contasse muito mais.

No século XIX, a partir de 1810, com a Abertura dos Portos às Nações Amigas (1808-1814) e o Tratado de Aliança e Amizade (1810), o Brasil se tornava interessante para um grupamento de judeus que sofria com problemas de pobreza, segregação, doenças, apedrejamento, conversão forçada e martírio no norte da África. Outros fatores foram importantes: intensifica-se a navegação no exterior com maior número de cargas e passageiros, aumentando o comércio de exportação e importação; facilitam-se as

Farto, Febos, Feijão, Feijó, Fernandes, Fernandez, Ferrão, Ferraz, Ferreira, Ferro, Fialho, Fidalgo, Figueira, Figueiredo, Figueiró, Figueiroa, Flores, Fogaça, Fonseca, Fontes, Forro, Fraga, Fragoso, França, Franco, Freire, Freitas, Fróis, Furtado, Gabriel, Gago, Galante, Galeno, Galo, Galvão, Gama, Gamboa, Ganso, Garcia, Gasto, Gil, Godinho, Goes, Gomes, Gonçalves, Gouveia, Gramacho, Guadalupe, Guedes, Guerra, Guerreiro, Gusmão, Henriques, Homem, Isidro, Jordão, Jorge, Julião, Lago, Laguna, Lara, Leal, Leão, Ledesma, Leitão, Leite, Lemos, Lima, Liz, Lobo, Lopes, Loução, Loureiro, Lourenço, Lousada, Lousano, Lucena, Luiz, Luna, Luzarte, Macedo, Machado, Madeira, Madureira, Magalhães, Maia, Maioral, Maldonado, Malheiro, Manganês, Manoel, Marçal, Marques, Martins, Mascarenhas, Matos, Matoso, Medalha, Medeiros, Medina, Melão, Melo, Mendanha, Mendes, Mendonça, Meneses, Mesquita, Miranda, Moeda, Molina, Monforte, Moniz, Monsanto, Montearroio, Monteiro, Montes, Montezinhos, Moraes, Morales, Morão, Moreira, Moreno, Mota, Moura, Munhoz, Nabo, Navarro, Negrão, Neves, Nobre, Nogueira, Noronha, Novaes, Nunes, Oliva, Olivares, Oliveira, Paixão, Pacheco, Paes, Paiva, Pantoja, Pardo, Paredes, Parra, Páscoa, Passos, Paz, Penalvo, Penha, Penteado, Peralta, Perdigão, Pereira, Peres, Pessoa, Pestana, Picanço, Pilar, Pimentel, Pina, Pineda, Pinhão, Pinheiro, Pinto, Pires, Pisco, Pizarro, Pombeiro, Ponte, Porto, Pousado, Prado, Preto, Proença, Quadros, Quaresma, Queirós, Quental, Rabelo, Ramalho, Ramires, Ramos, Rangel, Raposo, Rebelo, Rego, Reis, Resende, Ribeiro, Rios, Rocha, Rodrigues, Roldão, Romão, Romeiro, Rosário, Rosa, Rosado, Ruivo, Ruiz, Sá, Salvador, Samora, Sampaio, Sanches, Sandoval, Santarém, Santiago, Santos, Saraiva, Sarilho, Saro, Seixas, Sena, Serra, Serrano, Serrão, Silva, Silveira, Simão, Simões, Siqueira, Soares, Sodré, Soeiro, Sola, Souto-Maior, Souza, Tavares, Taveira, Teixeira, Teles, Tomás, Torres, Torrones, Tota, Tourinho, Tovar, Trigueiros, Trindade, Uchoa, Valladolid, Vale, Valente, Vargas, Vasconcelos, Vasques, Vaz, Veiga, Velasco, Vellez, Velho, Veloso, Vergueiro, Viana, Vicente, Viegas, Vieira, Vigo, Vila, Vila-Lobos, Vilanova, Vilar, Vila-Real, Vilela, Vizeu, Xavier, Ximenes, etc. (CARVALHO, F.M. 1992, p. 57-411) Isso nos daria um bom indício para reforçar uma ideia de que boa parte dos brasileiros de hoje são descendentes de cristãos novos. 


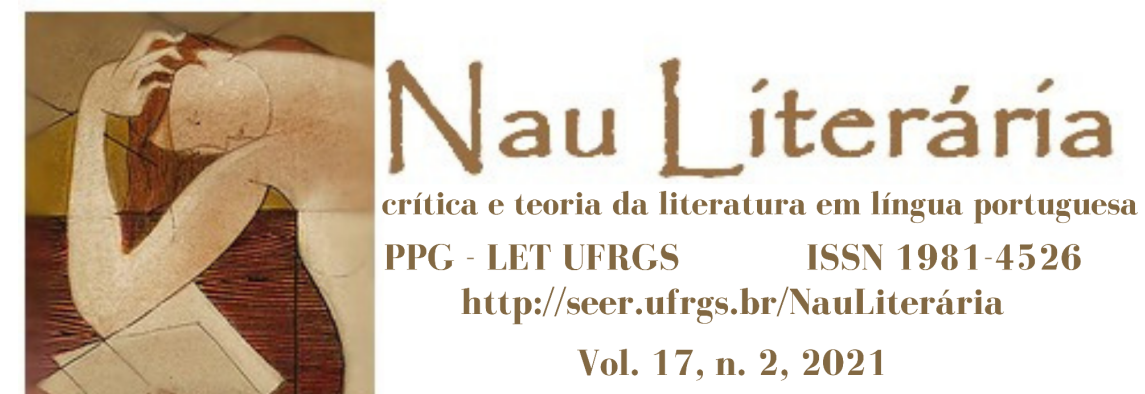

correntes migratórias judaicas pela calha central do rio Amazonas; também o surgimento do Ciclo da Borracha (1850-1910). (BENCHIMOL, 2008, p. 68-9) Calcula-se que aproximadamente mil famílias de judeus vieram para a Amazônia, entre 1810 e 1910. A maior parte que chegou para o norte do Brasil era de sefaraditas, de origem espanhola. Outros, em menor número, participaram também desse processo migratório: serfatitas (de origem francesa): askenazitas (de origem germânica, ou da Europa Central); foiquinitas (do Oriente Médio). (BENCHIMOL, 2008, p. 71-81) Graças à Aliança Israelita Universal - órgão responsável por expressar solidariedade aos judeus no mundo para sua "emancipação e progresso moral" - o emigrante que chegava à Amazônia do Marrocos já era um sujeito preparado e educado para se afirmar por meio de diferentes profissões no exterior e assim se agregar, com suas famílias, à nova "Terra da Promissão". (BENCHIMOL, 2008, p. 55-58)

No ensaio, “A verdadeira nação de Rafael Bentes”, Márcio Souza procura narrar o encontro com suas raízes judaicas; ele que, até certa altura da vida, desconhecia a relação com a sua origem, tanto nos lados paterno (Bentes) e materno (Sevalho). Ao descrever a sua chegada a Israel pela primeira vez, o ensaísta enfrenta a sua memória desconhecida:

\begin{abstract}
$\mathrm{Na}$ qualidade de sefaradi, os genes que me formaram deram milhares de volta pelos continentes desde que deixaram o Sião, na diáspora provocada pela invasão de Nabucodonosor, para finalmente me engendrarem e me permitirem chegar ao Muro das Lamentações. (SCLIAR, SOUZA, 2000, p. 88)
\end{abstract}

Interessante notar que o símbolo de uma fratura de povos venha a surgir de maneira tão peremptória ao primeiro contato com o seu judaísmo latente. O Muro das Lamentações pode ser visto como "separação entre irmãos exilados e os que ficaram; separação-fronteira-propriedade entre nações, tribos, indivíduos; separação entre famílias; separação entre Deus e a criatura". E mais: "o Muro (pode ser visto) como a comunicação cortada, com a sua dupla incidência psicológica; segurança, sufocação; 


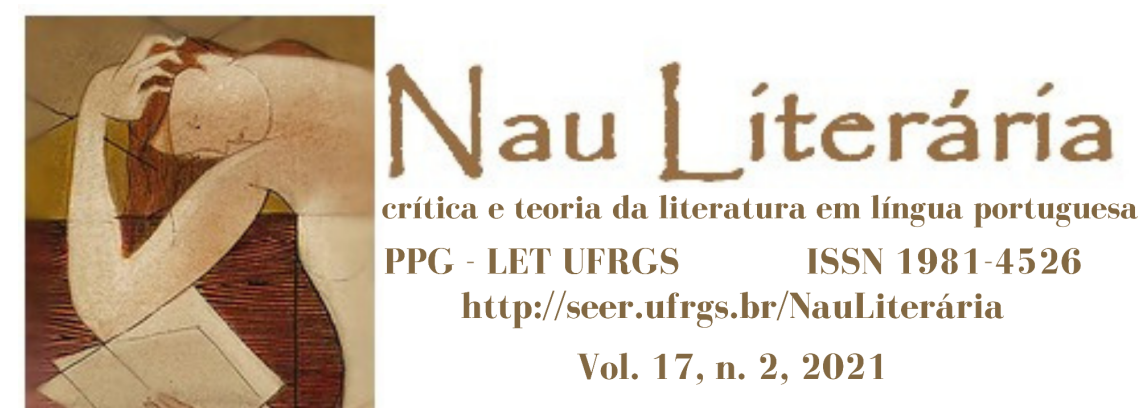

(mas também) defesa e (paradoxalmente) prisão". (CHEVALIER, GHEERBRANT, 2009 , p. 626) A necessidade de retorno a uma origem leva o narrador a remexer um imaginário de enfrentamento. As condições dadas lhe permitem chegar não a um fim, mas a um ponto de partida. O muro é a cisão que separa os seus dois eus: o do assimilado e o da essência judaica. O que lhe causa espanto e torna possível a capacidade de despertar para um problema de ser. A identidade que ele carregava se pulveriza diante da monumentalidade que o Muro propõe como objeto hermenêutico. $O$ que veremos no restante do ensaio é uma tentativa de localização muito mais no tempo e espaço imaginários.

A arquitetura urbana secular então traduz essa ânsia de projeção imaginária no ensaísta: "As ruelas e becos de Jerusalém evocam a força da tenacidade humana e tecem em sua estrutura urbana os meandros de uma cidade que é bem mais símbolo que propriamente geografia". (SOUZA, 2000, p. 90) O ensaísta está atrás de uma emancipação do eu sensível, como já percebemos anteriormente. As questões de memória dependem do poder de evocação do eu que a cidade suscita: “.,.assinalar a passagem de gentes tão díspares como Josué e Ricardo Coração de Leão, Herodes e Luís da França, Saladino e Jesus? Mas isto é Israel!” (SOUZA, 2000, p. 90) E outros monumentos e personagens históricos vão se misturando para construir uma trama referencial de partilha com as possibilidades de projeção e esgotamento, o que leva o eu a um limite entre passado e presente: as fortalezas arruinadas de São João d'Acre; Jericó e suas muralhas imaginárias; Reb Ieshu e a água que vira vinho; o lago de Tibaríade, onde se come o mesmo peixe que o pescador Shimon pescava; o oásis onde Salomão descansou; enfim, o berço da civilização ocidental, de onde surgiram, por meio de uma estratégia veloz de aproximação, como recurso narrativo, figuras contemporâneas como Marx, Freud e Einstein. (SOUZA, 2000, p. 90) O autor está à vontade para remexer sua trama de reconhecimento e recompor o cenário que melhor lhe aprouver diante do desafio de recosturar uma intriga involuntária. 


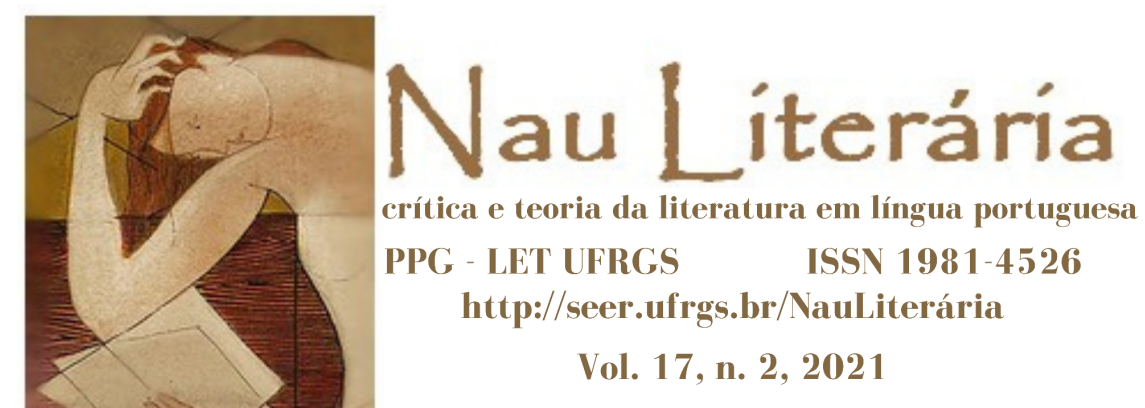

Em Israel, o autor joga seu eu em um imbróglio terminológico que impõe ao próprio sujeito investigador um fenômeno muito além da convergência iniciática: judeus hassidim, ${ }^{16}$ askhkenazi, sefaradi são trazidos à cena para colidir com os costumes modernos. (2000, p. 92) É a tradição pedindo para respirar pelo eu cultural, o sujeito que talvez não creia nos fundamentos básicos religiosos, mas que precisa ensaiar uma crença em si para poder entender a trama em que está envolvido o seu processo de mergulho nas raízes.

O processo de investigação suscitado pela ida a Israel leva o ensaísta de volta ao Brasil: a história de nosso país se confunde com a diáspora sefaradita. Os cristãos novos ("gente da nação") vindos para cá, desde os primeiros séculos da colonização, ajudaram a dar o perfil econômico, social e cultural que nos caracterizou como pátria ao longo dos séculos. (SOUZA, 2000, p. 93) Com a expulsão dos judeus de Portugal, este se torna o país mais atrasado da Europa. (SOUZA, 2000, p. 98) É evidente que para o ensaísta, reunir elementos que produzam os aspectos mais impactantes da inserção da cultura sefaradita na formação ibérica desde o período do medievo dará a ele instrumentos para ir mais fundo na sua história pessoal. Como faz parte de uma tradição de assimilados, tanto do lado paterno como materno, será pertinente que as referências sejam elencadas com uma força heráldica relevante: “...os Bentes se instalaram em Lisboa e se mostram extremamente maleáveis, a tal ponto que, na ocupação da região Amazônica, os Bentes aparecem já no século XVII, ora como magistrados, ora como militares". (SOUZA, 2000, p. 99) Ou, mais recentemente: "Meu bisavô Belarmino Bentes foi juiz de paz da comarca de Alenquer, Pará. Republicano e liberal, combateu sem trégua as arbitrariedades dos fazendeiros de cacau e pecuaristas do baixo Amazonas..." (SOUZA, 2000, p. 99) Ou: "No Amazonas começou a trabalhar como agrimensor (engenheiro Daniel Sevalho, seu bisavô do lado materno), um dos mais requisitados e bem

\footnotetext{
${ }^{16}$ Os judeus hassidins são ortodoxos que vão muito além dos estudos tradicionais. Parecidos com os haredis, considerados ultraortodoxos. Márcio Souza opta sempre pela citação na forma latina, por isso o uso do itálico.
} 


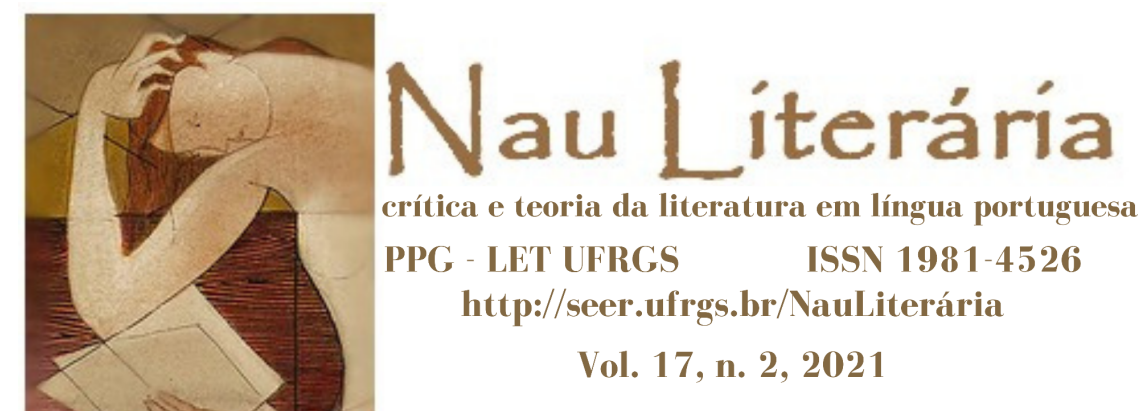

remunerados... brinquei muitas vezes no imenso quintal de sua mansão..." (SOUZA, 2000, p. 100) A recuperação dessa trajetória responde aos séculos de silêncio que ele encontrou em relação a sua ascendência judaica. Nesse caso, já não importa aqui o lado religioso, pois ele não quer seguir nenhuma linha doutrinária. $\mathrm{O}$ que quer é ir ao encontro dos retalhos de uma memória que não foi escrita. Faz também do esquecimento seu aliado nessa busca. Depara-se com lacunas palimpsésticas que se tornam ainda mais sedutoras. Os sobrenomes são relidos exatamente pelo que não foi registrado de um trajeto, escavando relíquias que podem estar em lembranças ou mesmo numa lápide abandonada de um cemitério. A história mutilada do judaísmo assimilado não pode esconder a força herdada em cada um dos seus descendentes e é isso que ele vê despertar no contato com a origem imaginária.

A modernidade chega à Amazônia, e ali estão seus antepassados, através do traço vertiginoso que completa o desenho que dá autoridade ao seu escrito: “O látex fez toda uma civilização no norte do Brasil e os sefaradim foram um importante instrumento civilizatório." (SOUZA, 2000, p. 105) Ao mexer com essas relíquias do passado remoto, a escrita se abisma, mas evita apelar para as imagens de imediato (sem mediação imagística), pois é preciso recuperar um percurso claudicante de ganhos e perdas por meio das identificações referenciais de início, ou em pontos estratégicos. $\mathrm{O}$ ensaísta é, na verdade, um emoldurador de um quadro, ou de um desenho que necessita da precisão cirúrgica dos complementos que não se fizeram num passado remoto, ou que ficaram faltando para que ele pudesse fazer o enlaçamento: “...os nomes sefaradim estão presentes em Cametá, Óbidos, Oriximiná, Alenquer, Santarém e Itaituba, no Pará, ou em Itacoatiara, Tefé e Manaus, no Amazonas. Foi uma imigração espontânea e descompromissada..." (SOUZA, 2000, p. 106) Essa é principalmente uma geografia de sensações, de percepções do que foi relevante para se permitir o trajeto do "testemunho de reconstrução", segundo a proposta benjaminiana. A imagem gradativa, ou de elenco, ou a mediadora, produz a cobertura de vasta área geográfica mais imemorial do que 


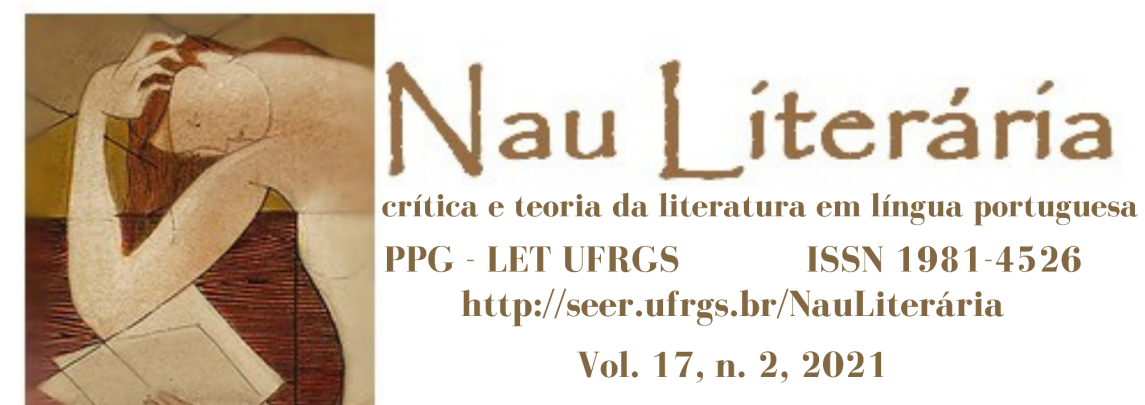

telúrica, ou fluvial, propriamente dita. A conquista perceptiva dá a sensação de que a história está em sua escrita de maneira completa, apesar dos hiatos subentendidos.

Mas o destino judaico na hinterlândia não foge ao destino da debacle do Ciclo da Borracha: "Por uma desenfreada entrega da Amazônia ao vitalismo econômico numa fictícia circulação de rendas, a região parece naufragar definitivamente no delírio." (SOUZA, 2000, p. 108) Ao entrelaçar as duas sagas, o ensaísta produz uma condução identitária que ajuda a configurar uma força invisível que vale a pena investigar. Relembramo-nos imediatamente os livros de grandes sucessos de público e crítica de Márcio Souza quando investiu, de maneira decisiva, nessa reconstrução de passados por meio de romances históricos que transacionaram através da loucura ou do fantástico, por meio de artifícios meta-ficcionais extremamente perspicazes e que ajudaram a compreender a Amazônia em partes estratégicas de sua recondução imaginária. Estamos falando principalmente de Galvez: imperador do Acre (1976), Mad Maria (1980), A resistivel ascensão do Boto Tucuxi (1982) e O fim do Terceiro Mundo (1990). ${ }^{17}$

A decadência inspirada na crise econômica sugere a equação que levará, mais adiante, a novos périplos da região e dos povos migrantes no vazio que ficará, trazendo novas possibilidades formais:

Cada salto na cotação da bolsa de Londres que a borracha sofria era uma erupção na placidez provinciana. Passo a passo, o enriquecimento conjurava o marasmo e representava uma conquista do refinamento civilizado. Concretamente, as circunstâncias não passavam de um furor do momento. Mesmo quando eram cômicas ou trágicas. (SOUZA, 2000, p. 108)

Judeus, juntos a outros povos, como cearenses ou sírio e libaneses, ajudaram a construir essa saga da Amazônia moderna. Mas a sua condição contemporânea não

\footnotetext{
${ }^{17}$ Considero $O$ fim do terceiro Mundo o seu grande romance. Aquele que funciona como uma súmula de todo o esforço souziano em tentar localizar de maneira radical a Amazônia no mundo contemporâneo, por meio da intertextualidade histórica e ficcional.
} 


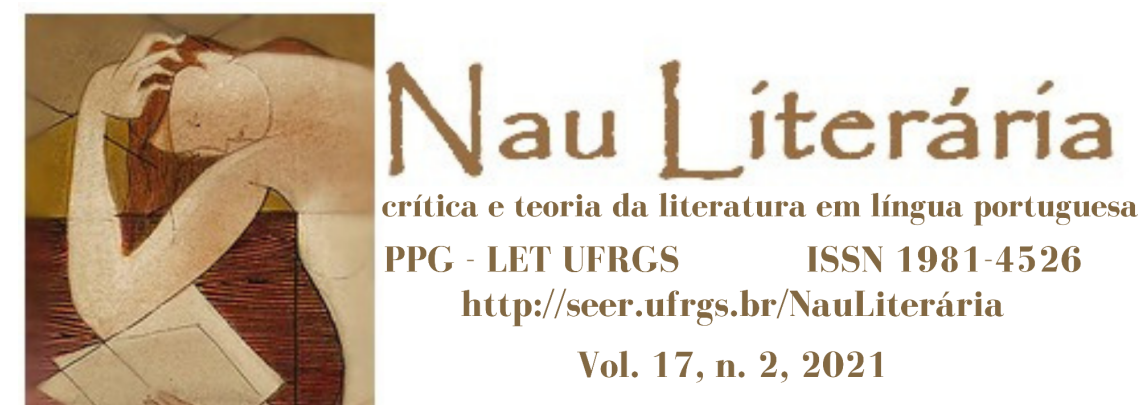

fugiu a peculiaridades que só o interior regional do grande vale verde sugeria para seus escritores e intelectuais. A dispersão se torna um ponto fundamental para entendermos a autoinserção do ensaísta ao reconstituir suas raízes. Por isso, não é difícil conceber que o "assimilado" precise de uma fluidez da memória para reativar as novas possibilidades de escrita: “...minha infância foi absolutamente distinta. Primeiro, eu não me identificava como judeu e nem era identificado como tal. Meus pais sempre deram pouca importância para as questões de religião..." (SOUZA, 2000, p. 112) O passado, na completa indiferença em relação à origem inicial, é o ponto de partida para a reconstituição de lembranças essenciais para a compreensão do fenômeno na região. Havia o menino judeu rico que dava a impressão ao ensaísta que era muito bom ser judeu; as duas meninas comunistas e judias que não assistiam à aula de religião; a ausência de culpa que os sefaraditas faziam questão de enfatizar pela crucificação de Cristo, pois hipoteticamente já tinham chegado a Espanha muito antes do evento de Herodes $;{ }^{18}$ o rabino Moyal que no início do século XX chega à Amazônia em busca de donativos para a construção de uma escola teológica em Jerusalém; Moyal morre de gripe espanhola, e acaba enterrado em um cemitério cristão, tornando-se uma espécie de santo judeu (são Moisezinho milagroso), fundando um lugar de peregrinação até os tempos atuais. (SOUZA, 2000, p. 113-4) Todos esses fatos mencionados representam eventos estratégicos na construção da escrita e da leitura privilegiada que o ensaísta vai trazendo para o seu campo de controle. É o ser judeu que fala por meio dos rastros que são recolhidos.

O ensaísta se dá conta que "o grande perigo enfrentado pelos judeus na Amazônia não é exatamente o antissemitismo, mas a assimilação." (SOUZA, 2000, p. 115) A ideia de que houve o apagamento, ou o esquecimento da origem judaica, não faz desparecer os rastros. Todos eles subentendidos, ou reconvertidos ao seu lugar

\footnotetext{
${ }^{18}$ Como curiosidade, explica-se que os judeus usavam esse argumento contra os altos impostos que o governo espanhol, na Idade Média, impunha a eles.
} 


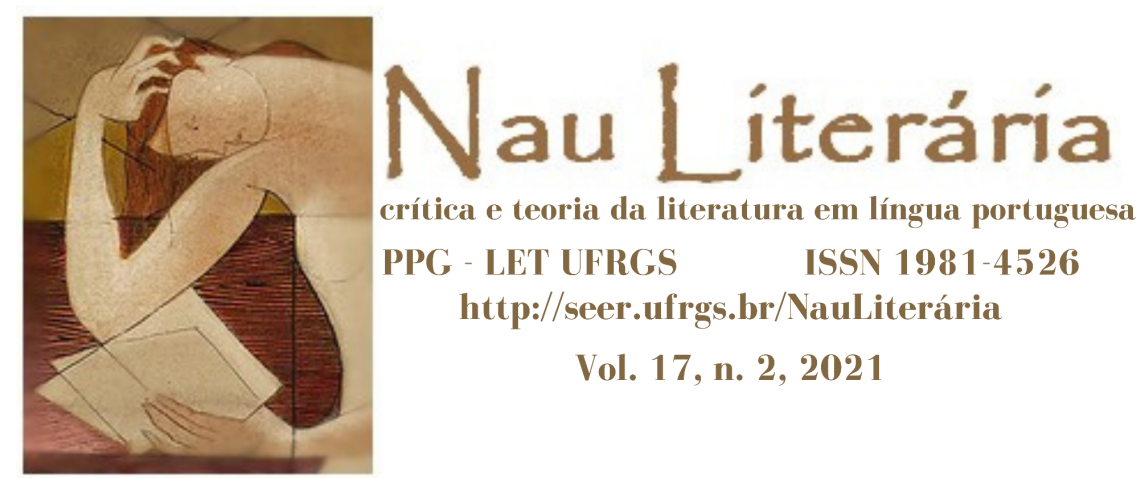

problemático de revisão privilegiada: “...foi graças aos estudos do professor Samuel Benchimol sobre a presença dos judeus na Amazônia. Só então ficamos sabendo - com orgulho - de nossas origens judaicas.” (SOUZA, 2000, p. 115) A mediação, por meio do grande pesquisador, enfim, produz o impacto que levou o ensaísta a se situar como um membro de uma comunidade na Amazônia. Não no aspecto religioso, como já enfatizei em outros momentos, mas sobretudo como pertencente a um sentido identitário que o leva a uma origem de construção ou nomeação de toda uma esfera regional de que ele, e sua família, são elos indissociáveis. Claro, muito mais relevante do que o ensaísta acreditava até então no momento da descoberta. Esse entrelaçamento, através dos elementos dispersos, dão sentido a toda a trajetória de um povo, na verdade. A sua questão pessoal e o fato de se assumir como judeu dão ao escritor uma situação diferenciada no panorama regional da literatura brasileira na Amazônia. ${ }^{19}$

O enfrentamento para dar um sentido ao judaísmo recém-adquirido se propõe por várias frentes, como por exemplo quando um primo do seu pai não aceita "o seu quinhão de sangue impuro":

Para ele, em sua versão revisionista da família, o nome Bentes é de origem norte-americana, originária de um dos confederados que se estabeleceram em Santarém após a derrota do Sul. De minha parte, entre ser descendente de um escravagista sulista ou de um intrépido judeu que não quis seguir para o exílio na Babilônia, fico com este último. Para completar, ser parente do professor Samuel Benchimol é uma grande honra. (SOUZA, 2000, p. 115)

\footnotetext{
19 Tive a oportunidade de conhecer pessoalmente Márcio Souza em 2009, por conta de um evento comemorativo na universidade em que trabalho, no interior da Amazônia. Fiquei surpreso que ele havia lido o meu livro sobre a região, onde eu dou destaque à sua obra. Apesar de já ter ouvido falar sobre o fato, logo no início da palestra, ele se assumia como judeu sefaradita. Achei extraordinário, mas fiquei indiferente a isso por anos, até finalmente ler, recentemente, o ensaio "A verdadeira nação de Rafael Bentes", publicado em 2000. Acho que fiquei devendo essa faceta da obra desse autor a quem tanto admirei quando escrevia a minha tese de doutorado. Lembro-me de termos passado várias horas conversando, madrugada adentro, em um restaurante, sobre diferentes assuntos, inclusive sobre suas viagens a Israel. Apesar de toda a admiração a sua ascendência judaica, ele deixou claro que achava um absurdo qualquer fanatismo religioso, coisa que ele presenciou em sua estadia por lá, principalmente, em Jerusalém.
} 


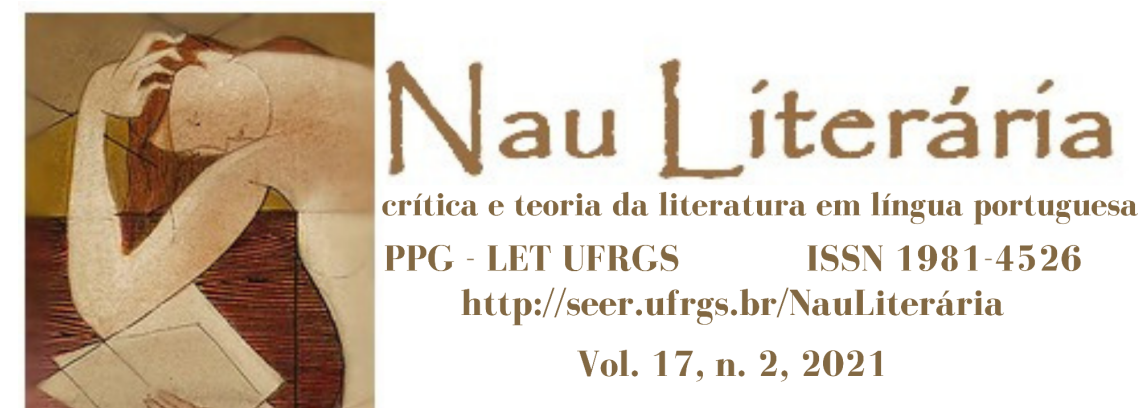

Ao não ter receio de confrontar a falsa versão das origens familiares, o ensaísta se rende a uma circulação cósmica e inconsciente que o leva a um poder subterrâneo que lhe dará condições de ser um sonhador de raiz, conforme a compreensão de Bachelard, e o leva também a se referir a dois mundos por meio da representação poética, ou literária (FERREIRA, 2013, p. 170). Sua percepção da trajetória de seus antepassados mostra uma força e coragem para encenar o possível da raridade das sensações:

O drama do isolamento sempre foi uma realidade na Amazônia, e não apenas para os judeus. Mas a faina do regatão, o comerciante que viajava pelos rios vendendo mercadorias e comprando produtos da safra, e os serviços de administração e guarda-livros das propriedades extrativistas sempre foram trabalhos exercidos por imigrantes ainda jovens, alguns solteiros, outros casados, na solidão dos grandes ermos amazônicos. As reuniões de família só ocorriam muito raramente, por ocasião das grandes festas religiosas como Rosh Hashaná, Iom Kipur, Pessach etc. (SOUZA, 2000, p. 115-6)

Pensar a raiz é um convite a ir sempre longe, na perspectiva bachelardiana. É sempre estar atrás do perdido (FERREIRA, 2013, p. 171). É isso que faz o ensaísta, talvez com uma precisão e desenvoltura que, fosse um poeta de profissão, talvez não pudesse alcançar com tamanha lucidez. A imagem cobra o tributo em diferentes instâncias. No ensaio, a imagem se entrega, na maioria das vezes, sub-repticiamente, quando um autor de talento sabe que não pode ficar no simples namoro dos fatos, ou nas elucubrações imediatas que lhe são legadas pelas vozes confusas. É preciso dar ordem e organização ao processo que o invade e lhe mostra novos caminhos de compreensão: "O isolamento pela Amazônia aos judeus produziu insólitos resultados.” (SOUZA, 2000, p. 116) Ao olhar para si e os outros, o ensaísta se mistura à terra que acolheu seus antepassados. Não importa a miscelânea que resultou desse processo. A terra engole 


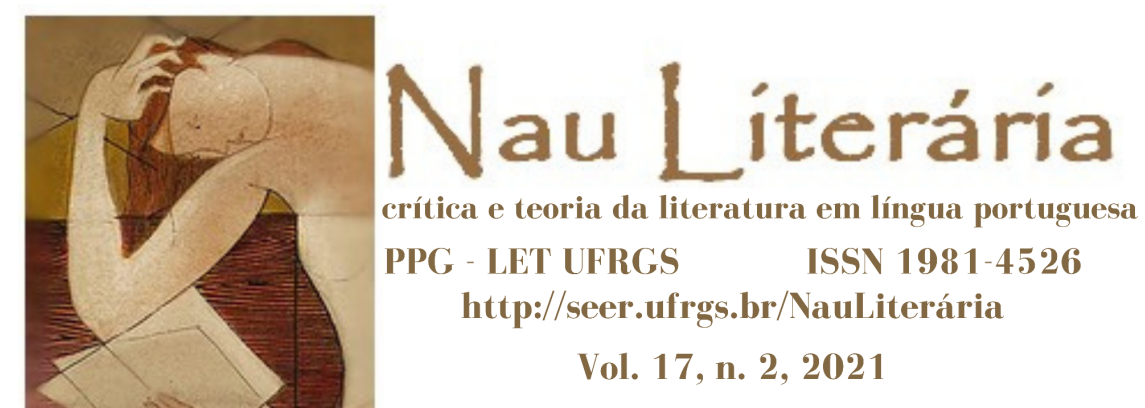

tudo e deixa para a escrita o dever de desvendar o oculto. Os fatos narrados por ele demonstrarão o quanto da força de origem é capaz de se revelar por meio da coragem da escrita. A Amazônia é desvelada em partes que a tornam um todo complexo e desafiador para recompor o seu sentido simbólico para o mundo.

Ao contestar um diplomata israelense quanto ao número de judeus no Brasil, em contraponto ao elevado número de "árabes”, o ensaísta reforça o seu entrelaçamento com os rastros simbólicos: “...quanto aos judeus o diplomata limitava-se a contar apenas os religiosos, os frequentadores de sinagoga esquecendo os marranos, os cristãos novos, os assimilados, os laicos, enfim, uma parte significativa da população brasileira." (SOUZA, 2000, p. 118) Trata-se aqui de um momento significativo de afirmação da sua judeidade, pois sua implicância de ser depende sobretudo dessa interligação com o hipotético, com o subentendido, pois é uma história que não pode mais ser negada, a partir do momento em que você se vê conduzido por forças de risco e reconhecimento muito mais fortes do que a racionalidade e a cronologia comum seriam capazes de arriscar a apreender.

A última lembrança, o fechamento hipotético do ensaio, é um retorno ao momento da cisão. Ali, em Israel, o ensaísta lida com uma particular sensação de reafirmar o que as pistas já tinham deixado bem claras em seu coração:

...então o Muro das Lamentações é ainda mais sagrado, porque foi gerado na humildade dos desvalidos e resistiu para dizer às gerações que as nações também pagam caro pelos seus erros. E algumas nunca mais encontram seu caminho de volta. Nesse dia, bati minha cabeça nas pedras do Kotel e pensei na minha família. Um judeu em seu reencontro. (SOUZA, 2000, p. 119)

O deparar-se com o seu destino de ser, é uma maneira de revitalizar seu imaginário e sua identidade. Dar-se conta do judaísmo, traz o desafio de recuperar as tantas marcas de um imbróglio que nunca cessará de pulsar a partir da segregação que seus antepassados se viram obrigados a sofrer, sempre predispostos a sobreviver através 


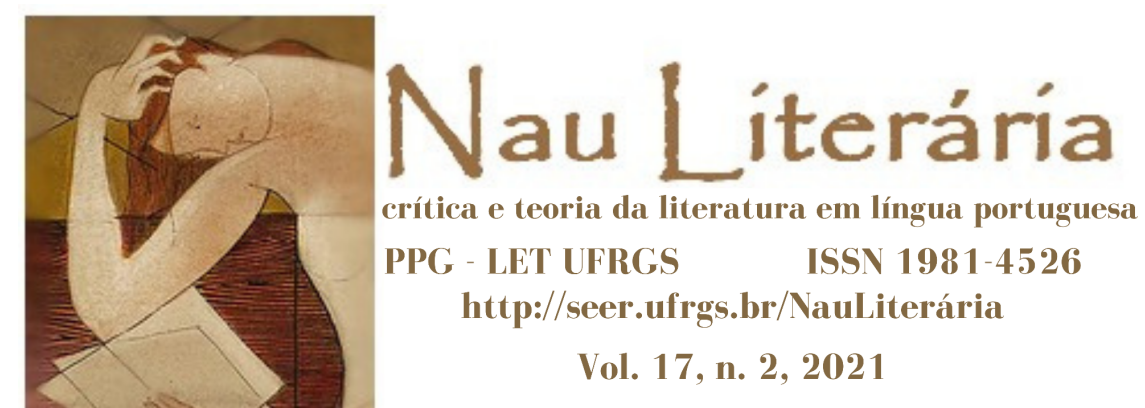

de um vagar nômade, a se dispersar em rincões como os da Amazônia. A fundação de Israel não resolvem os impasses seculares sofridos por esse povo. O ensaísta se reconcilia com seu passado partido.

Retomando a questão das nomenclaturas, para concluir, é certo que qualquer epíteto depende das condições onde ele é usado. Márcio Souza e uns tantos outros podem ser encaixados como escritores de expressão judaica, não há dúvida. No caso dele, principalmente depois que escreveu o ensaio que aqui foi analisado. Mas também como antes poderia ser visto como um escritor de alma amazônica. Uma coisa não invalida a outra. O judaísmo e a itinerância amazônica estão imbricadas. O importante é nunca limitar o autor nesse ou naquele enquadramento para o alcance de compreensão de sua obra ou poética. Um grande autor são vários. Sua condição étnica não pode limitá-lo a uma circunscrição apenas de interesse por parte da crítica. Ele tem o direito de ser sempre visto sob vários ângulos performáticos. O judaísmo será uma das facetas importantes da obra de Márcio Souza.

\section{REFERÊNCIAS:}

BENCHIMOL, S. Eretz Amazônia: os judeus na Amazônia. Manaus: Valer, 2008.

CARVAlHO, J. C. Amazônia revisitada: de Carvajal a Márcio Souza. Rio Branco: Edufac, 2005.

CARVALHO, Flávio Mendes. Raízes judaicas no Brasil: o arquivo secreto da inquisição. São Paulo: Nova Arcádia, 1992.

CHEVAliER, J., GHEERBRANT, Alain. Dicionário de símbolos: mitos, sonhos, costumes, gestos, formas, figuras, cores, números. 24.ed. Rio de Janeiro: José Olympio, 2009.

FERREIRA, A. E. A. Dicionário de imagens, símbolos, mitos, termos e conceitos bachelardianos. Londrina: Eduel, 2013. 


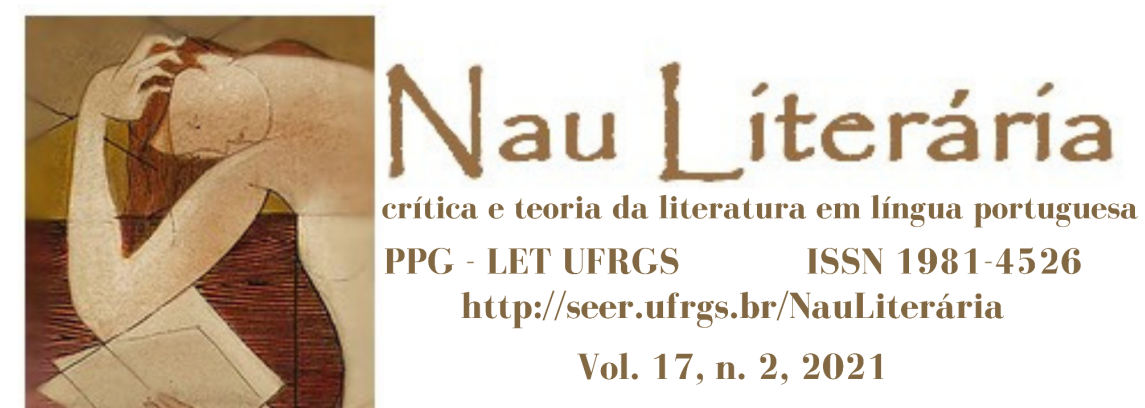

FERREIRA, T. C. M. Eu sou uma pergunta: uma biografia de Clarice Lispector. Rio de Janeiro: Rocco, 1999.

IGEL, R. "Escritores judeus brasileiros: um percurso em andamento". Porto Alegre. Revista Ibero americana. Vol. LXVI, n. 191. Abr-jun 2000. P. 325-338.

$\begin{array}{llll}\text { Acesso em } & \text { setembro } & \text { de }\end{array}$ https://revista-iberoamericana.pitt.edu/ojs/index.php/Iberoamericana/article/viewFile/57 $\underline{72 / 5918}$

LAUB, M. Diário da queda. São Paulo: Companhia das Letras, 2011.

SCLIAR, M. A estranha nação de Rafael Mendes. 2.ed. São Paulo, Círculo do Livro, 1990.

. "Memórias judaicas". In: SCLIAR, M., SOUZA, M. Entre Moisés e Macunaíma: os judeus que descobriram o Brasil. Rio de Janeiro: Garamond, 2000.

SHAPIRO, H. L. O povo da terra prometida. In.: COMAS et al. Raça e ciência I. São Paulo: Perspectiva, 1970. P. 111-188

SILVA, M. S-. Catástrofe, história e memória em Walter Benjamin e Chris Marker: a escritura. História, memória, literatura: o testemunho na era das catástrofes. Campinas: Unicamp, 2003. P. 387-413

SOUZA, M. Galvez: imperador do Acre. 4.ed. Rio de Janeiro: Brasília/Rio, 1977.

. Mad Maria. Rio de Janeiro: Civilização Brasileira, 1980.

. A resistível ascensão do Boto Tucuxi. Rio de Janeiro: Marco Zero, 1982.

. O fim do Terceiro Mundo. São Paulo: Marco Zero, 1990.

. "A verdadeira nação de Rafael Bentes". In: SCLIAR, M., SOUZA, M. Entre Moisés e Macunaíma: os judeus que descobriram o Brasil. Rio de Janeiro: Garamond, 2000 .

Cadernos de literatura brasileira. São Paulo: Instituto Moreira Sales, 2005. 